\title{
Some Reflections on the Contribution of Donald Kommers
}

\author{
By Gary Jacobsohn*
}

Publius concluded his series of papers in defense of the new U.S. Constitution by saying: "I am persuaded that it is the best which our political situation, habits, and opinions will admit."1 It remained for his successors to investigate the numerous ways in which even this imperfect instrument provided at best a partial blueprint for organizing the nation's business. This they have done with mixed success. Among the most accomplished in this ongoing enterprise have been visitors from faraway places - Alexis de Tocqueville is the leading example - who have brought a fresh perspective to their appraisal of constitutional arrangements that have eluded many of our homegrown investigators. ${ }^{2}$

The passing of Don Kommers is an opportunity to acknowledge that there have been exceptions to the parochialism of the American public law scholarly community, and that Don was among the most distinguished and insightful of this small group. He was a pioneer in demonstrating the ways in which foreign experience might illuminate and possibly enrich American constitutional understandings. I don't know if Don was familiar with the music of the American folk singer, Tom Waits; my guess is that he was not. But I'm sure he would have nodded approvingly had he heard Waits sing this line from one of his songs: "I never saw my hometown until I stayed away too long."

If Waits was not known to Don, the eminent legal theorist, Roscoe Pound, surely was. Indeed, Pound's encomium for the comparative method encapsulates my friend and colleague's strongest scholarly commitment: "Experience, which is no longer merely local, must be subjected to the scrutiny of reason and developed by reason, and reason, which in its very nature transcends locality, must be tested by experience. The wider the experience, the better is the test. Thus the science of law must increasingly be comparative. Whether we are dreaming of a world law or thinking of the further development of our own law...the methods of the jurist must have a basis in comparison." 4

While the framers of the American Constitution may have proceeded in accordance with this insight, the comparative method became for many years marginalized as a tool of constitutional analysis. This is especially the case in the United States, where the longevity of the Constitution has

\footnotetext{
${ }^{\star}$ H. Malcolm Macdonald Professor of Constitutional and Comparative Law in the Department of Government and Professor of Law at the University of Texas at Austin.

${ }^{1}$ The Federalist No. 85 (Alexander Hamilton).

${ }^{2} \mathrm{See}$ Alexis de Tocqueville, Democracy in America: The Complete and Unabridged Volumes I and II (Henry Reeve trans., 2000).

${ }^{3}$ Tom Waits, San Diego Serenade, on The Heart of Saturday Night (Asylum Records, 1974).

${ }^{4}$ Roscoe Pound, Foreword to A. von Mehren, The Civil law System: Cases and Materials for the Comparative STUDY OF LAW, at vii-viii (1957).
}

() 2019 The Author. Published by Cambridge University Press on behalf of the German Law Journal. This is an Open Access article, distributed under the terms of the Creative Commons Attribution-NonCommercial licence (http://creativecommons.org/licenses/by/4.0/), which permits unrestricted re-use, distribution, and reproduction in any medium, provided the original work is properly cited. 
surely contributed to a discernible insularity (and perhaps arrogance) in scholarly and juristic awareness of alternative constitutional possibilities. No one did more to resist this regrettable development than Don Kommers, whose intimate familiarity with the substance of the German constitutional order opened a window into the constitutionalism of his own country, and in so doing, showed us all the worth of the comparative method.

Don was deservedly honored by the German legal establishment, and on one such occasion he used the acceptance of an honorary Doctor of Laws to consider the lessons to be learned from the German constitutional model. His speech at that ceremony later was published, in an English-language translation, as the essay "Can German Constitutionalism Serve as a Model for the United States?" $\mathrm{He}$ pointed out that much had been written about American influence on constitutional developments around the world, but precious little could be found describing the reverse vector of influence. Given that, in Don's judgment, "Germany's Basic Law has replaced the American Constitution as the world's leading model of democratic constitutionalism," American scholars and judges would be foolish if they ignored the instructional possibilities inherent in this new reality. ${ }^{6}$ Don's essay is republished in this memorial collection.

"[C]onvinced that judicial cases are wonderful tools for bridging legal cultures," Don was careful to avoid any simplistic approach that would crudely adopt outcomes from one national jurisdiction for application to another. ${ }^{7}$ Instead, his method was to isolate a distinguishing regime characteristic of the polities under his scrutiny and then proceed, in Tocquevillian fashion, to reflect on the constitutional implications that extended from this assessment. So, in the German and American cases, Don's contrast of the constitutive significance of the German prioritizing of dignity and the American emphasis on liberty produced wonderfully insightful conclusions about the scope and meaning of rights and responsibilities in their respective regimes. One could disagree with these conclusions on such issues as religious liberty, free speech, and abortion, and still remain grateful for receiving his fascinating lessons in comparative constitutional analysis, which in Don's own words is "a field of scholarly inquiry" whose "real intellectual challenge" is "to identify the moral, political, and social theories that help to explain different outcomes and different styles of reasoning from country to country."

Don's absorption with this challenge extended to his firm commitment to correctly educating students whose initial academic exposure to the American Constitution was an introductory course in constitutional law. That meant providing them with the comparative materials that would allow them to situate their own constitutional norms and practices within a broader global context. I was privileged to be one of his collaborators in the construction of a constitutional law textbook that featured just such an approach. He was the real inspiration behind this effort; as he put it, "[T]he study of American constitutional law should be informed by the great variety and richness of comparative materials now available in other constitutional democracies." 9

The fourth edition of this text was published shortly before Don left us. The work on its revisions and additions corresponded with the progression of his fatal disease. Because of this he was unable to contribute as he had hoped, for which he was, true to his character as a real "mensch," unnecessarily apologetic. In an email he wrote; "I'm getting more and more excited about the 4th

\footnotetext{
${ }^{5}$ See Donald P. Kommers, Can German Constitutionalism Serve as a Model for the United States?, 58 ZEITSCHRIFT FÜR AUSLÄNDISCHES ÖFFENTLICHES RECHT UND VÖLKERRECHT 787 (1998).

${ }^{6} I d$. at 788 .

${ }^{7} I d$. at 789 .

${ }^{8} I d$. at 798 .

${ }^{9}$ See Donald Kommers et al., American Constitutional Law: Governmental Powers and Democracy $\left(4^{\text {th }}\right.$ ed. 2018).
} 
edition as I begin to catch up on the Supreme Court's work after a bad illness and after devoting most of my time to another book project. I am really looking forward to working with each of you." And later he wrote: "Seems to me that we have the opportunity now to do a lot of rethinking about the 4th edition and to produce a con law book that will stand the test of time." If it does, it will be because of Don Kommers' example and his inspiration.

It was Don who wrote to me to tell me of our good friend Walter Murphy's passing some years ago. "He will be missed as I will miss him. May he rest in peace." You too, Don, you too. 